\title{
In Memoriam. Dr. Sergio Ayala Sandoval
}

\author{
In Memoriam. Sergio Ayala Sandoval, M.D.
}

Dra. Laura Estefanía Aguilar-Sierra*

* Médico Anestesiólogo
Adscrito. Hospital Regional
ISSEMyM, Nezahualcóyotl.
Maestría en Administración
Hospitalaria y Salud Pública.

Citar como: Aguilar-Sierra LE. In Memoriam. Dr. Sergio Ayala Sandoval. Rev Mex Anestesiol. 2022; 45 (1): 74. https:// dx.doi.org/10.35366/102908

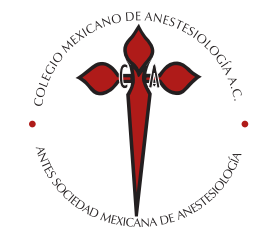

Correspondencia:

Dra. Laura Estefanía Aguilar-Sierra E-mail: lagujilar@hotmail.com

C ómo recordar a un amigo con el corazón en la mano y una copa de vino.

Una tarea muy difícil para honrar a un amigo, anécdotas e historias que se guardan en el corazón, un amigo de 20 años. Hablar de su vida profesional, todos conocimos esa parte, comprometido con su trabajo hasta el último día.

Lo conocí en un Diplomado de arbitraje médico, a su lado su gran amigo, el Dr. Carlos Rodolfo Moreno Alatorre. Iniciamos un proyecto para mejorar las demandas a las que se enfrentaban nuestros compañeros anestesiólogos ante la Comisión Nacional de Arbitraje Médico (CONAMED) que ocupaban el tercer lugar en cuanto a otras profesiones; ahí inicia el proyecto Curso de peritos en el Colegio Mexicano de Anestesiología, los primeros alumnos recibieron la información del quehacer del «perito». Posteriormente, el Dr. Ayala presenta su propuesta: el Curso de Responsabilidades Jurídicas en el Profesional de la Salud, en el cual no sólo se convocaba a médicos, sino también a enfermeras, abogados y todo aquel profesional interesado en conocer las causas de quejas ante la CONAMED. Trabajamos en equipo, integrando a otro de sus más queridos amigos, el Dr. Fernando Alfaro Victoria. Así, se conformó un grupo firme que a través de la recopilación de información y revisión de publicaciones dio como resultado de esas largas tardes y grandes pláticas, la planeación y organización del curso. Dos años más tarde se integra el Lic. Gerardo Martínez Ortiz y salimos avante con el curso durante trece años con éxito. La vida siguió, los capitanes del barco partieron, dejando un vacío insustituible, nadie los pudo suplir. Cierto día le dije: «No deje el barco». Y respondió firme como siempre: «No, no, lo haré». Sólo fue por muy corto tiempo.

En su última llamada telefónica, que fue el cumpleaños 91 de mi mamá, preguntó por ella y dijo: «Ya no voy a llegar a esa edad». Platicó de sus proyectos en el Consejo Nacional de Certificación en Anestesiología, sus grandes pendientes.

Hoy ya se extrañan esas largas conversaciones planeando su curso, platicaba anécdotas de su época de residente, recordaba a sus grandes maestros que dejaron huella en él, que le enseñaron a ser anestesiólogo, del crecimiento de su Colegio y de su vida personal. Así fueron las últimas conversaciones con el Dr. Ayala.

Honrar a todos sus amigos fue algo que él hubiera querido, pues dejaron un gran vacío que no pudo llenar. Hoy entiendo por qué platicaba una y otra vez la misma historia, sencillo: recordar lo hacía vivir.

Lo despedimos sus hijos Gabriel y Perla Ayala, su más querido alumno Dr. David García Arreola y yo, su amiga de historias.

Lo recordaré vestido formalmente de traje, con su sonrisa amable, esa mirada que acaricia el alma y hace que se abra el corazón.

Hasta siempre. No es un adiós, lo volveremos a ver.

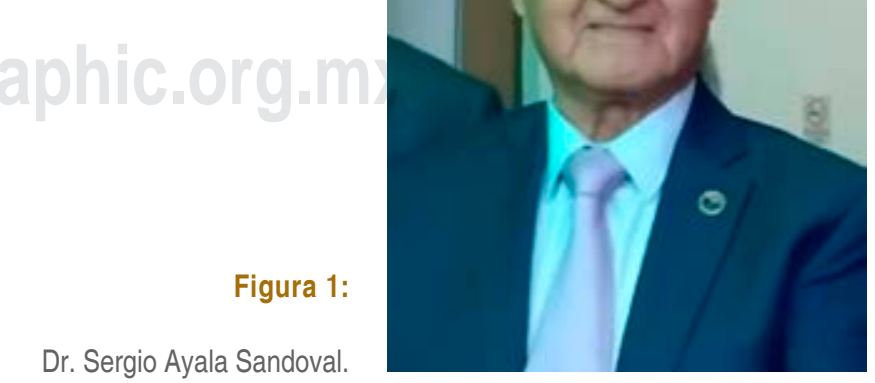

